Poligami Bagi Aparatur...(Rahmayani Saragih) DOI: https://doi.org/10.30596/dll.v3i2.3160

\title{
POLIGAMI BAGI APARATUR SIPIL NEGARA BERDASARKAN UNDANG-UNDANG NOMOR 1 TAHUN 1974 TENTANG PERKAWINAN
}

\author{
Rahmayani Saragih \\ Kantor Wilayah Kementerian Hukum dan Hak Asasi Manusia Sumatera Utara \\ Jl. Putri Hijau No. 4, Medan - Sumatera Utara. \\ Email: rahmayanisaragih@gmail.com
}

\begin{abstract}
Abstrak
Undang-Undang Nomor 1 Tahun 1974 tentang Perkawinan, ketentuan tentang perkawinan telah diatur yang berlaku untuk semua warga negara Indonesia, termasuk mereka yang merupakan warga negara berstatus pegawai negeri sipil. Pegawai negeri harus memberikan contoh yang baik kepada bawahan mereka dan memberi contoh sebagai warga negara yang baik di masyarakat, juga dalam mengatur kehidupan keluarga. Dalam UndangUndang Nomor 1 Tahun 1974 disebutkan "Perkawinan adalah ikatan batin dan lahiriah antara laki-laki dan perempuan sebagai suami-istri dengan tujuan membentuk keluarga / rumah tangga yang bahagia dan kekal berdasarkan Satu Ketuhanan, dan dicatat sesuai dengan yang berlaku undang-undang ". Tentunya pernikahan abadi adalah impian semua keluarga. Pada prinsipnya, dalam perkawinan seorang pria mungkin hanya memiliki seorang istri dan seorang istri mungkin hanya memiliki seorang suami, tetapi itu tidak mengesampingkan kemungkinan bahwa seorang suami memiliki lebih dari satu istri (poligami) bersamaan dengan kondisikondisi tertentu, ini juga berlaku untuk pegawai negeri sipil pria setelah persyaratan tertentu dipenuhi.
\end{abstract}

\section{Kata Kunci: Poligami, Aparatur, Sipil, Negara, Perkawinan}

\section{Abstract}

Law Number 1 of 1974 concerning Marriage, provisions concerning marriage have been regulated which apply to all Indonesian citizens, including those who are citizens of the status of civil servants. Civil servants must set a good example to their subordinates and set an example as good citizens in the community, also in organizing family life. In Law No. 1 of 1974 stated "Marriage is an inner and outer bond between a man and a woman as husband and wife with the aim of forming a happy and eternal family / household based on the One Godhead, and recorded according to the applicable legislation". Surely eternal marriage is the dream of all families. In principle, in a marriage a man may only have a wife and a wife may only have a husband, but it does not rule out the possibility that a husband has more than one wife (polygamy) at the same time with certain conditions, this also applies to a male civil servant after certain conditions are met.

\section{Keywords: Polygamy, Government Employees, State, Marriage}

\section{PENDAHULUAN}

Masalah poligami selalu menarik perhatian. Tidak saja bagi kaum laki-laki yang sebagian besar menjadikan poligami sebagai obsesinya. Namun juga bagi kaum perempuan yang tidak menyukai poligami dan menganggapnya sebagai suatu yang membahayakan kedudukan dan perannya sebagai seorang istri. 
DE LEGA LATA

Jurnal Ilmu Hukum

FAKULTAS HUKUM UMSU
Poligami Bagi Aparatur...(Rahmayani Saragih)

Volume 3 Nomor 2, Juli-Desember 2018, 230-243 DOI: https://doi.org/10.30596/dll.v3i2.3160

Poligami kembali menarik perhatian ketika Menteri Negara Pemberdayaan Perempuan, Khofifah Indar Parawangsa (pada masa Beliau menjabat sebagai Menteri Pemberdayaan Perempuan) menyatakan perlunya mengkaji ketentuan Peraturan Pemerintah No. 45 Tahun 1990 tentang Perubahan Atas Peraturan Pemerintah Nomor 10 Tahun 1983 Tentang Izin Perkawinan dan Perceraian Bagi Pegawai Negeri Sipil, khususnya mengenai aturan bagi pegawai negri untuk berpoligami. Ralitasnya menunjukkan kurang efektifnya ketentuan tersebut, yaitu meskipun pegawai negeri diberikan rintangan untuk berpoligami, namun banyak penyimpangan dilakukan.

Undang-Undang perkawinan sebenarnya menganut asas monogami dalam suatu perkawinan. Di sisi lain, jika hukum agama mereka memungkinkan dan para pihak menghendaki, poligami diperbolehkan dengan syarat yang cukup ketat. Namun akibat sulitnya prosedur yang harus dijalani, tidak jarang mereka melakukan jalan pintas melalui pernikahan siri atau pernikahan dibawah tangan atau hidup bersama tanpa ikatan pernikahan.

Hal tersebut dianggap lebih mudah dari pada mengajukan permohonan berpoligami ke pengadilan dengan prosedur yang lebih rumit. Alternatif menikah siri yang memenuhi kaidah agama, tetapi tidak diakui secara hukum, dianggap sebagai jalan keluar termudah. Tanpa disadari melalui pernikahan siri, seorang perempuan tidak memperoleh perlindungan hukum atas ikatan perkawinan yang dilakukannya. Suatu perkawinan yang tidak dicatat pada kantor pencatatan nikah, baik Kantor Catatan Sipil atau Kantor Urusan Agama maka diianggap tidak sah oleh Negara walaupun perkawinan itu sudah sah menurut agama. Apabila hal itu terjadi, yang paling dirugikan tentu perkawianan itu dianggap tidak pernah terjadi oleh Negara.

Pada dasarnya Undang-Undang Nomor 1 Tahun 1974 menganut asas monogami, dengan tetap membuka kemungkinan peluang dalam hal tertentu diperbolehkannya berpoligami dengan syarat yang cukup berat. Penerapan asas tersebut berdasarkan pada keyakinan yang ada dalam masyarakat bahwa terdapat agama yang secara tegas menganut asas monogami dan melarang tindakan poligami, tetapi ada pula agama yang memungkinkan tindakan poligami dalam kondisi tertentu dengan dengan ketentuan yang ketat. Pembuat undang-undang berupaya menangkap aspirasi yang tumbuh dimasyarakat. Oleh karena itu hukum yang baik adalah hukum yang mampu menyerap aspirasi nilai-nilai yang berkembang di masyarakat.

Sementara, dalam pandangan lain hal ini dianggap sebagai suatu bentuk ketidakkonsistenan Undang-Undang Perkawinan. Diterapkannya asas monogami dengan memungkinkannya kondisi tertentu membuat poligami dinilai sebagai wujud ketidak tegasan. Menurut mereka, poligami mewujudkan adanya diskriminasi karena hal itu dinilai memposisikan perempuan lebih rendah dari pada laki-laki dalam suatu institusi perkawinan. Poligami dipandang sebagai bentuk pengunggulan laki-laki terhadap perempuan.

Pandangan tersebut tidak sepenuhnya benar. Apabila poligami dilakukan atas dasar memperturutkan hawa nafsu, hanya sekedar mewujudkan egoisme laki-laki, berarti benar telah terjadi pengunggulan laki-laki terhadap perempuan. Namun, jika tindakan poligami dilakukan sebagai terakhir dalam penyelesaian kasus dalam hal agama dan kebaikan kedua 
Jurnal Ilmu Hukum

FAKULTAS HUKUM UMSU
Poligami Bagi Aparatur...(Rahmayani Saragih)

Volume 3 Nomor 2, Juli-Desember 2018, 230-243 DOI: https://doi.org/10.30596/dll.v3i2.3160

belah pihak, maka pandangan tersebut kurang tepat. Poligami harus dipandang sebagai suatu kemungkinan yang dapat dilakukan secara selektif dan hati-hati.

Di dalam tulisan ini akan dikaji permasalah poligami ditinjau dari aspek hukum normatif berdasarkan Undang-Undang Nomor 1 Tahun 1974 tentang Perkawinan, begitu juga dengan Peraturan Pelaksana Undang-Undang Nomor 1 Tahun 1974 yang khusus mengatur izin poligami bagi pegawai negeri sipil. Pengungkapan beberapa kasus yang terjadi dalam masyarakat dimaksudkan untuk memperjelas uraian dalam bahasan.

\section{METODE PENELITIAN}

Jenis penelitian yang digunakan dalam penelitian tesis ini adalah penelitian yuridis normatif yaitu penelitian yang difokuskan untuk mengkaji kaedah-kaedah hukum atau norma-norma (Jhony Ibrahim, 2008, h. 282) dalam hal ini berkaitan dengan aspek hukum normatif berdasarkan Undang-undang Nomor 1 Tahun 1974 tentang Perkawinan begitu juga dengan Peraturan Pelaksana Undang-Undang Nomor 1 Tahun 1974 yang khusus mengatur izin poligami bagi pegawai negeri sipil.

Sifat penelitian ini mempergunakan metode deskriptif analisis, dengan pendekatan kualitatif. Penelitian deskriftif analisis adalah penelitian dengan penelusuran dokumen atau lebih banyak dilakukan terhadap data yang bersifat sekunder yang ada di perpustakaan. Penelitian normatif dapat dikatakan juga dengan penelitian sistematik hukum sehingga bertujuan mengadakan identifikasi terhadap pengertian-pengertian pokok/dasar dalam hukum, yakni masyarakat hukum, subyek hukum, hak dan kewajiban, peristiwa hukum, hubungan hukum dan obyek hukum (Jhony Ibrahim, 2008, h. 282).

Teknik pengumpulan data yang digunakan untuk menganalisis data dalam penelitian ini adalah menggunakan pengumpulan data sekunder dari studi pustaka atau studi dokumen yang relevan dengan penelitian ini di perpustakaan dan melakukan indentifikasi data. Data yang diperoleh melalui penelitian kepustakaan tersebut selanjutnya akan dipilih guna memperoleh peraturan-peraturan di dalam Undang-Undang terkait, yang berisi kaedah-kaedah hukum yang kemudian dihubungkan dengan permasalahan yang dihadapi dan disistematikakan sehingga menghasilkan klasifikasi yang selaras dengan penelitian ini

\section{PEMBAHASAN}

\section{Asas Monogami dalam Undang-Undang Nomor 1 Tahun 1974 tentang Perkawinan}

Undang-Undang Dasar Negara Republik Indonesia 1945 menegaskan "Setiap warga Negara bersamana dengan kedudukannya di dalam hukum pemerintahan dan wajib menjunjung hukum dan pemerintah itu dengan tidak ada kecualinya". Dari rumusan tersebut dimaksudkan bahwa setiap warga Negara, baik laki-laki maupun perempuan memiliki kedudukan sama dalam hukum tanpa kecuali.

Bersesuaian dengan ketentuan UUD 1945 tersebut, jika dilihat dari ketentuan dalam Pasal 1 Undang-Undang Nomor 1 Tahun 1974 tentang Perkawinan. Tampak bahwa kedudukan hukum antara laki-laki dan perempuan adalah sama. Ketentuan tersebut menyatakan bahwa kedudukan hukum antara suami dan istri dalam keluarga adalah seimbang 
DE LEGA LATA

Jurnal Ilmu Hukum

FAKULTAS HUKUM UMSU
Poligami Bagi Aparatur...(Rahmayani Saragih)

Volume 3 Nomor 2, Juli-Desember 2018, 230-243 DOI: https://doi.org/10.30596/dll.v3i2.3160

dan sederajat. Hal tersebut bersesuaian dengan Pasal 30 dan Pasal 31 dari ketentuan tersebut yang menunjukkan adanya keseimbangan antara hak dan kewajiban suami dan istri dalam rumah tangga dan tata pergaulan masyarakat.

Berdasarkan ketentuan tersebut Undang-Undang Nomor 1 Tahun 1974 tentang Perkawinan tampak cukup mencerminkan asas non diskriminasi. Meskipun dalam beberapa hal, ketentuan tersebut bagi sebagian pihak masih dianggap menyiratkan suatu diskriminasi terhadap perempuan. Yaitu dalam kaitannya dengan masalah poligami. Berkenaan dengan hal itu, beberapa pandangan menyatakan perlunya suatu pedoman pelaksanaan dari ketentuan tersebut agar lebih mewujudkan rasa keadilan.

Asas monogami dalam ketentuan perkawinan menjadi dambaan kebanyakan perempuan. Sebab, asas tersebut dianggap mampu melindungi kepentingan kaum perempuan dari keinginan dan kesewenang-wenangan suami untuk menikah lagi. Oleh karena itu, dalam proses penyusunan Undang-Undang Nomor 1 Tahun 1974 tentang Perkawinan, kaum perempuan meskipun mendapat tantangan dari pihak-pihak yang menganggap dalam hal-hal darurat tertentu harus dimungkinkan perkecualian atau diperbolehkan berpoligami. Dengan demikian, ditetapkan asas monogami dalam Undang-Undang Nomor 1 Tahun 1974 tentang Perkawinan dan diperbolehkannya suatu poligami dalam keadaan memaksa dan darurat memadukan dua pandangan yang ada dalam masyarakat.

Pada dasarnya, Undang-Undang Perkawinan menganut asas monogami, bahwa dalam suatu perkawinan, seorang laki-laki hanya diperbolehkan mempunyai seorang istri dan seorang perempuan hanya diperbolehkan mempunyai seorang suami. Namun, ketentuan selanjutnya membolehkan adanya suatu poligami apabila para pihak menghendaki dan karenanya pengadilan dapat memberi izin kepada suami untuk beristri lebih dari seorang. Ketentuan yang membolehkan poligami tersebut sebenarnya disertai alasan yang cukup berat. Walaupun dalam peraktiknya ada kecendrungan bisa diperbolehkan.

Berdasarkan ketentuan tersebut Undang-Undang Nomor 1 Tahun 1974 tentang Perkawinan tampak cukup mencerminkan asas nondiskriminasi. Meskipun dalam beberapa hal, ketentuan tersebut bagi sebagian pihak masih dianggap menyiratkan suatu diskriminasi terhadap perempuan. Yaitu dalam kaitannya dengan masalah poligami. Berkenaan dengan hal itu, beberapa pandangan menyatakan perlunya suatu pedoman pelaksanaan dari ketentuan tersebut agar lebih mewujudkan rasa keadilan.

Asas monogamy dalam ketentuan perkawinan menjadi dambaan kebanyakan perempuan. Sebab, asas tersebut dianggap mampu melindungi kepentingan kaum perempuan dari keinginan dan kesewenang-wenangan suami untuk menikah lagi. Oleh karena itu, dalam proses penyusunan Undang-Undang Nomor 1 Tahun 1974 tentang Perkawinan, kaum perempuan meskipun mendapat tantangan dari pihak-pihak yang menganggap dalam hal-hal darurat tertentu harus dimungkinkan perkecualian atau diperbolehkan berpoligami. Dengan demikian, ditetapkan asas monogami dalam Undang-Undang Nomor 1 Tahun 1974 tentang Perkawinan dan diperbolehkannya suatu poligami dalam keadaan memaksa dan darurat memadukan dua pandangan yang ada dalam masyarakart. 
Jurnal Ilmu Hukum FAKULTAS HUKUM UMSU
Poligami Bagi Aparatur...(Rahmayani Saragih) Volume 3 Nomor 2, Juli-Desember 2018, 230-243 DOI: https://doi.org/10.30596/dll.v3i2.3160

Pada dasarnya, Undang-Undang Nomor 1 Tahun 1974 tentang Perkawinan menganut asas monogami, bahwa dalam suatu perkawinan, seorang laki-laki hanya diperbolehkan mempunyai seorang istri dan seorang perempuan hanya diperbolehkan mempunyai seorang suami. Namun, ketentuan selanjutnya membolehkan adanya suatu poligami apabila para pihak menghendaki dan karenanya pengadilan dapat memberi izin kepada suami untuk beristri lebih dari seorang. Ketentuan yang membolehkan poligami tersebut sebenarnya disertai alasan yang cukup berat. Walaupun dalam peraktiknya ada kecendrungan bisa diperbolehkan.

\section{Asas Poligami Dimungkinkan dalam Undang-Undang Nomor 1 Tahun 1974 tentang Perkawinan dengan Sistem Ketat}

Sebagaimana telah disebutkan bahwa meskipun Undang-undang Perkawinan pada dasarnya menganut asas monogami namun dalam hal tertentu, yaitu jika kedua belah pihak menyetujuinya dan telah dipenuhi dengan alasan dan persyaratan yang telah ditentukan, poligami di perbolehkan, jika memenuhi syarat tertentu.

\section{Alasan Diperbolehkan Poligami}

Prosedur untuk berpoligami sebenarnya sangat berat. Secara hukum, pengajuan kepengadilan untuk berpoligami harus disertai alasan.

a. Istri tidak dapat menjalankan kewajibannya

b. Istri memiliki cacat badan atau penyakit yang tidak dapat disembuhkan

c. Istri tidak dapat melahirkan keturunan.

Ketiga alasan tersebut bersifat kumulatif. Artinya, seorang suami dibolehkan berpoligami jika istrinya memiliki salah satu kelemahan tersebut. Alasan pertama dan kedua saling berkaitan, yaitu dalam hal tidak dapat menjalankan kewajiban sebagai seorang istri dan adanya cacat badan atau penyakit baik jasmani maupun rohani yang dapat disembuhkan sehingga tidak memungkinkan menjalankan kewajiban sebagai istri.

Beberapa pandangan menganggap dasar alasan tersebut bersifat diskriminatif dan memojokkan posisi perempuan untuk terpaksa harus menerima poligami jika memiliki kelemahan sebagai mana dinyatakan dalam pasal tersebut. Dari alasan yang dikemukakann oleh Undang-Undang Perkawinan tersebut, tersirat bahwa poligami pada hakekatnya merupakan bentuk pengunggulan kaum laki-laki dan penegasannya bahwa berfungsi istri dalam perkawinan hanya untuk melayani suami.

Pandangan tersebut tidak sepenuhnya benar karena dasar filosofi dimungkinkannya poligami dalam Undang-Undang Perkawinan lebih mulia dari pada sekedar ke egoisan pemuasan hawa nafsu. Banyak kasus lolosnya permohonan izin berpoligami dengan mengabaikan ketentuan Undang-Undang Perkawinan tidak bisa dijadikan alasan menuding Undang-Undang sebagai diskriminatif, tetapi aspek penegakan hukumnya yang harus ditegakkan. Contohnya, pengadilan dan pejabat atasan harus benar-benar selektif dan hati-hati sebelum mengabulkan permohonan untuk berpoligami. 
DE LEGA LATA

Jurnal Ilmu Hukum

FAKULTAS HUKUM UMSU
Poligami Bagi Aparatur...(Rahmayani Saragih) Volume 3 Nomor 2, Juli-Desember 2018, 230-243 DOI: https://doi.org/10.30596/dll.v3i2.3160

\section{Istri Tidak Dapat Menjalankan Sebagai Istri}

Alasan ini tampak seperti sesuatu yang wajar. Tetapi, kalau kita cermati serasa aneh : seorang istri yang terkait pernikahan mengalami ketidak mamouan dalam melaksanakan kewajiban sebagai seorang istri. Pasti ketidak mampuan tersebut diakibatkan oleh tifldak adanya suatu penyakit, trutama atas suatu kejadian, atau hal lain yang menakutkan. Dasar bahwa istri tidak dapat menjalankan kewajiban sebagai istri harus dibuktikan dengan fakta, misalnya istri sakit sehingga tidak memungkinkan untuk melayani suami. Dengan demikian, hal tersebut tidak boleh ditentukan secara sepihak oleh suami agar memungkinkan ia beristri lagi ataupun rekayasa kesepakatan kedua belah pihak.

Memang realitasnya menunjukkan bahwa sering kali ketentuan tersebut diterapkan secara serampangan dengan mengesampingkan rasa keadilan bagi pihak perempuan. Berbagai kasus yang ada menampakkan pemutarbalikan fakta. Misalnya seorang suami yang meninggalkan istri dalam jangka waktu yang cukup lama kemudian menceraikan sang istri dengan alasan tidak menjalankan kewajiban memenuhi kebutuhan batin suami.

Kasus lain, seorang istri yang merasa sakit hati dan kewalahan menghadapi tabiat suaminya yang terlalu "bermain-main" dengan perempuan lain. Akhirnya, dia tidak sanggup membiarkan kelakuan suaminya tersebut dan terpaksa merelakan suaminya menikah lagi atas dasar alasan tidak dapat menjalankan kewajiban sebagai seorang istri. Meskipun ketidakmampuan memenuhi kewajiban tersebut lebih didasarkan pada "kejijikan" atau ketakutan tertular penyakit kotor, si istri terpaksa mengambil keputusan membolehkan suami berpoligami dan anak-anaknya yang membutuhkan figur seorang ayah.

Di dalam kasus terakhir, mestinya pengadilan tidak serta mengabulkan permohonan poligami tersebut. Seharusnya, hakim secara cermat berhati-hati sebelum mengambil keputusan membolehkan seorang laki-laki berpoligami. Jika permasalahan sebenarnya adalah yang "sakit" dia harus mencoba diembuhkan lebih dahulu. Hal ini penting agar timbul pandangan yang menganggap alasan untuk berpoligami bisa diatur dengan mudah.

\section{Istri Memiliki Cacat Badan Atau Penyakit yang Tidak Dapat Disembuhkan}

Alasan kedua membolehkan seoarang laki-laki berpoligami adalah jika si istri memiliki cacat badan atau memiliki penyakit yang tidak dapat disembuhkan lagi. Dari perspektif perempuan, sebenarnya kenyataan ini menyakitkan dan dianggap tidak adil. Pada saat ia mengalami cobaan besar mengalami kecelakaan atau penyakit yang mengakibatkan cacat badan atau penyakit yang sulit disembuhkan. Istri harus merelakan suami yang dicintainya menikmati kebahagiaan dengan perempuan lain.

Dilihat dari sisi seorang laki-laki, dibolehkannya berpoligami berdasarkan alasan itu dianggap sebagai penyelesaian yang cukup adil dari melakukan zina. Meskipun seorang lakilaki mampu berempati atas musibah yang dialami istrinya. Baginya terasa sulit memenuhi kebutuhan biologisnya tanpa tahu sampai kapan si istri mampu sehat kembali. Untuk itu, dibutuhkan pengorbanan seorang istri untuk merelakan suaminya berpoligami akibat kelemahan yang dia alami. 
DE LEGA LATA

Jurnal Ilmu Hukum

FAKULTAS HUKUM UMSU
Poligami Bagi Aparatur...(Rahmayani Saragih) Volume 3 Nomor 2, Juli-Desember 2018, 230-243 DOI: https://doi.org/10.30596/dll.v3i2.3160

Hal yang penting adalah pengertian cacat badan harus diberi batasan yang jelas dalam kaitannya dengan ketidak mampuan istri melaksanakan kewajiban terhadap suaminya. Jadi, harus dikaitkan dengan alasan pertama. Pengertian cacat badan tidak boleh diartikan secara luas dan merugikan seorang istri hanya demi kepentingan suami beristri lagi.

\section{Istri Tidak Dapat Melahirkan Keturunan}

Memiliki keturunan dari sebuah pernikahan merupakan harapan hampir semua pasangan suami istri.melalui kelahiran seorang anak diharapkan akan menjadi tali penyambung keturunan selanjutnya. Selain itu, kelahiran seorang anak dianggap tali kasih yang erat antara suami-istri. Oleh karena itu, banyak suami atau istri kecewa ketika mengetahui pasangannya tidak mungkin memberikan anak yang akan menjadi tumpuan harapan dan kebahagiaan. Dengan demikian, seakan menjadi wajar jika seorang suami menunut diperbolehkan menikah lagi karena ketidak mampuan istri melahirkan seorang anak.

Meskipun demikian, patut direnungkan apakah kebahagiaan keluarga tidak mungkin tercapai tanpa kelahiran seorang anak langsung dari rahim istrinya? Banyak pasangan suamiistri yang kesulitan memperoleh anak. Tetapi dapat menikmati kebahagiaan dengan mengasuh anak orang lain atau tinggal berdua.

Tindakan mengasuh anak orang lain merupakan suatu perbuatan mulia dalam mengatasi pemasalahan kesulitan memperoleh keturunan. Tidak jarang terjadi, beberapa saat kemudian, si istri malah melahirkan buah hati yang ditunggu-tunggu. Dalam tradisi Jawa, tindakan mengasuh seorang anak bagi suami-istri yang kesulitan memproleh keturunan dimaksudkan untuk "memancing" dan diharapkan setelah seorang perempuan merasakan kasih sayang mengasuh anak terseut akan menjadi tenang perasaannya dan tertular sehingga dia dapat memiliki anak dari rahimnya.

Kasus yang ada dalam masyarakat tak jarang membuktikan kebenaran tradisi "memancing" anak tersebut. Umumnya, mereka mengambil anak dari kalangan famili mereka yang kurang mampu atau dari panti asuhan. Seperti psikologis, tindakan mengasuh anak 'membuat pasangan suami-istri menjadi tenang 'tidak ngoyo' dan mengurangi beban mental kesulitan mendapat anak yang mereka idamkan.

Hal ini yang perlu disoroti dalam kaitannya dengan alasan istri tidak dapat melahirkan, selain upaya alrernatif yang harus dilakukan sebelum memutuskan berpoligami adalah aspek keadilan. Urgensi mengenai hal ini dimaksudkan untuk mencegah egoisme suami berpoligami dengan merugikan dan mengesampingkan perasaan keadilan seorang istri.

Contoh kasus menunjukkan bahwa ada seorang istri dipaksa menyetujui permintaan suami untuk menikah lagi dengan alasan tidak mampu melahirkan anak. Padahal menurut keterangan dokter, si istri dalam keadaan sehat dan sebenarnya kelemahan terletak pada diri suami, menikah berkali-kali pun akan tetap kesulitan untuk memprolh anak, kecuali adanya keajaiban atas kuasa Allah SWT.

Di dalam kasus seorang istri dipaksa mengijinkan suaminya menikah lagi akibat cacat badan atau karena penyakit yang sulit disembuhkan. Munculnya pertanyaan apakah jika hal 
Jurnal Ilmu Hukum FAKULTAS HUKUM UMSU
Poligami Bagi Aparatur...(Rahmayani Saragih) Volume 3 Nomor 2, Juli-Desember 2018, 230-243 DOI: https://doi.org/10.30596/dll.v3i2.3160

yang sama dialami oleh seorang suami, dalam hal dia divonis dokter tidak subur, apakah tindakan istri meminta cerai dan menikah lagi dengan laki-laki lain dianggap adil dan tidak pantas untuk dilakukan, Pada saat sang suami menderita cacat badan atau penyakit yang tidak tersembuhkan yang selayaknya membutuhkan uluran tangan istri, tindakan yang dilakukan istri dalam menghadapi suatu cobaan bersama dalam meniti kehidupan rumah tangga.

Sesungguhnya, dasar perkawinan menurut Undang-Undang Perkawinan adalah ikatan lahir batin antara seorang laki-laki dan seorang perempuan sebagai suami-istri dengan tujuan membentuk keluarga (rumah tangga) yang bahagia dan kekal berdasarkan Ketuhanan Yang Maha Esa. Meniti hidup berdua bail pada saat tenang maupun sedih, ringan sama dijinjing berat sama dipikul.

\section{Syarat-Syarat Diperbolehkannya Poligami}

Pengajuan permohonan kepada pengadilan untuk berpoligami harus disertai dengan syarat-syarat yang sebenarnya cukup berat yaitu :

a. Adanya persetujuan dari seorang istri atau istri-istri lain jika telah memiliki beberapa istri

b. Adanya kepastian bahwa suami mampu menjamin keperluan-keperluan hidup istri-istri dan anak-anak mereka

c. Adanya jaminan bahwa suami akan melakukan adil terhadap istri-istri dan anak-anak mereka

Ketentuan syarat-syarat tersebut bersifat kumulatif dalam arti bahwa kesemua syarat tersebut harus terpenuhi dan dibuktikan dengan persetujuan untuk diperbolehkannya berpoligami. Agar lebih jelas, setiap syarat tersebut akan diuraikan satu persatu dalam pembahasan di bawah ini.

\section{Persetujuan Dari Istri atau Para Istri}

Pada hakekatnya, sulit bagi seorang perempuan untuk menerima kenyataan berbagi dengan perempuan lain dalam kehidupan rumah tangganya, kenyataan tersebut sangat manusiawi karena hal yang sama akan mengalami pula oleh seorang laki-laki. Sebagaimana seorang perempuan, seorang laki-laki akan sulit menerima kenyataan hal yang sama, akibat kelemahan yang dia miliki, pasangan hidupnya berpaling kepada orang lain. Meskipun secara kodrat memang tidak dimungkinkan untuk berpoliandari. Poin yang ingin disampaikan adalah kesadaran suami untuk berhati-hati sebelum mengambil keputusan dan mampu berempati memahami dan merasakan perasaan sang istri dalam hal dimadu.

Bahkan, ada kasus yang sampai melakukan ancaman kekeraan fisik utuk memperoleh persetujuan dari istrinya agar diperbolehkan menikah lagi, kasus lainnya melalui bentuk pemalsuan surat persetujuan ataupun mencuri cap jempol sang istri saat tidur.Meskipun demikian, bahkan berarti seorang perempuan harus bersikeras tidak mau memberi persetujuan kepada suaminya untuk poligami jika mendapat alasan untuk itu dan syarat-syarat yang di tentukan telah dianggap terpenuhi. Sebagai contoh, berikut ini sebuah kasus yang dialami seorang istri yang mendapati kenyataan bahwa suami memiliki masalah dalam kehidupan seksualnya, yakni menderita hiperseks. 
Jurnal Ilmu Hukum

FAKULTAS HUKUM UMSU
Poligami Bagi Aparatur...(Rahmayani Saragih) Volume 3 Nomor 2, Juli-Desember 2018, 230-243 DOI: https://doi.org/10.30596/dll.v3i2.3160

Pada awalnya, si istri berusaha memahami tuntutan suami dalam hal berhubungan seksual. Namun, lama kelamaan sang istri merasa tersiksa dan merasa tidak mampu memenuhi hasrat luar biasa sang suami. Kenyataan lain, si istri tetap merasa tidak rela dan tidak memperbolehkan suaminya untuk tidak menikah lagi. Menurut pandangan sang istri, lebih baik suaminya melakukan dengan orang lain (berzina) tanpa harus terikat dalam suatu pernikahan resi. Dengan tegas ia menyatakan, "lebih baik jajan diluaran, tetapi jangan bawa piringnya kerumah".

Pada akhirnya ikatan rumah tangga tersebut benar-benar tidak dapat dipertahankan karena suami menderita penyakit kotor menular, sang istri mengalami depresi berat akibat perasaan tertekan, dan anak-anak menjadi broken home tidak memperoleh panutan kehidupan yang baik dari orang tuanya. Kekerasan sikap istri yang egois, kurang mampu memahami permasalahan yang terjadi, menjadikan perkawinan mereka kandas ditengah jalan. Kasus tesebut merupakan bentuk penyimpangan komitmen dalam perkawinan, kesepakatan untuk mengangkatkan diri baik lahir maupun batin sebagai suami dan istri untuk membentuk keluarga bahagia sesuai dengan tuntunan tuhan.

\section{Kepastian Jaminan Suami Terhadap Keperluan Hidup Istri-Istri dan Anak-Anak}

Syarat ini mungkin tidak terlalu sulit kalau suami memiliki kemampuan dibidang materi yang cukup sehingga kemungkinan terus memberikan kewajiban nafkah untuk para istri dan anaknya. Namun, kasus yang ada dimasyarakat tidak demikian. Banyak suami dari kalangan menengah kebawah kurang berkecukupan memberanikan diri berpoligami. Hal tersebut pada akhirnya memperparah kondisi ekonomi istri dan anak-anak sebelumnya serta membuat mereka lebih menderita. Kadang kala, hal tersebut dianggap sebagai suatu tantangan bagi kaum laki-laki dengan menyatakan "kalau seorang tukang becak, tukang parkir, atau petani mampu beristri lebih dari satu, mengapa saya tidak melakukannya?"

Masih ingat kasus di Sampang yang menghebohkan masyarakat? Sasudin, seorang laki-laki muda asal Madura yang belum berpenghasilan tetap, langsung menikah empat orang perempuan sekaligus sebagai istrinya secara siri. Ketika ditanya alasannya keinginannya menikahi empat orang perempuan sekaligus, dia menyatakan bahwa sudah menjadi tekadnya untuk berpoligami. Jika ayahnya mampu menikah sampai 27 kali, mengapa dia tidak bisa menikah hanya empat orang perempuan? Dari pernyataan tersebut tersirat bahwa tujuan dilakukan tindakan poligami adalah untuk pemuasan hawa nafsu dan egoisme semata. Jauh menyimpang dari ketentuan-ketentuan UU Perkawinan.

Meskipun kasus poligami tersebut hanya berdasarkan hukum agama, menyimak dari kasus itu, hikmah yang bisa diambil adalah pengadilan harus berhati-hati dalam mengabulkan izin berpoligami.Untuk itu, Peraturan Pemerintah Nomor 9 Tahun 1975 tentang Pelaksanaan Undang-Undang Nomor 1 Tahun 1975 menentukan bahwa pengadilan dapat memeriksa ada atau tidak adanya kemampuan suami untuk memenuhi keperluan hidup istri-istri dan anakanaknya dengan memperlihatkan; surat ketengan mengenai penghasilan suami, yang ditanda tangani oleh bendahara tempat suami bekerja, surat keterangan pajak penghasilan, surat 
DE LEGA LATA

Jurnal Ilmu Hukum

FAKULTAS HUKUM UMSU
Poligami Bagi Aparatur...(Rahmayani Saragih) Volume 3 Nomor 2, Juli-Desember 2018, 230-243 DOI: https://doi.org/10.30596/dll.v3i2.3160

keterangan lain yang dapat diterima oleh pengadilan.

Proses pemeriksaan pnghasilan suami oleh pengadilan ini harus dihadiri oleh istri pertama atau istri-istri dari pernikahannya sebelumnya. Hal tersebut dimaksudkan agar proses tersebut bersifat objektif dengan diketahui oleh pihak yang terlibat. Memperhatikan kebutuhan hidup para istri dan anaknya adalah kewajiban suami yang harus dilakukan sesuai dengan kemampuannya.

Kepastian jaminan dari suami untuk memenuhi kebutuhan istri-istri dan anak-anaknya harus ditegaskan dalam suatu perjanjian. Hal itu penting karena sering terjadi suami ingkar janji, tidak terlaksanakan kewajiban terhadap istri dan anak-anak dari perkawinan terdahulu sesuai dengan kesepakatan, sehingga mengakibatkan istri yang memiliki penghasilan sendiri menjadi telantar begitu juga dengan anak-anak mereka. Rupanya, setelah menikah lagi terdapat kecendrungan bahwa suami melupakan istri dan anak-anak dari perkawinan sebelumnya karena sibuk mencukupi kebutuhan keluarga dari perkawinan terbaru.

\section{Adanya Jaminan Bahwa Suami Akan Berlaku Adil Terhadap Istri-Istri dan Anak-Anak Mereka}

Syarat ketiga tentang keadilan ini sangat penting untuk menjaga perasaan istri-istri dan anak-anak melalui adanya perlakuan yang tidak diskriminatif. Tindakan adil tersebut meskipun mudah diucapkan, sangat sulit diwujudkan. Kasus-kasus yang ada membuktikan betapa sulitnya seorang suami mewujudkan keadilan bagi istri-istri dan anak-anaknya. Sering kali, istri dan anak anak dari perkawinan dahulu merasa lebih banyak menjadi korban diperlukan tidak adil dibandingkan dengan perlakuan pada istri dan anak-anak dari perkawinan kemudian.

Guna mencegah hal tersebut terjadi, pengadilan perlu melakukan pemeriksaan adanya jaminan bahwa suami akan berlaku adil dalam memenuhi kewajibannya dengan memerintahkan suami membuat surat perjanjian tersebut secara tertulis. Jaminan bahwa suami akan berlaku adil terhadap istri-istri dan anak-anak mereka tersebut dapat ditunjukkan dengan suatu surat pernyataan janji dari suami.

Apabila kesemua syarat tersebut dianggap cukup terpenuhi dan ada alasan sebagai dasar untuk berpoligami, pengadilan akan memberi izin. Namun, dalam praktiknya, sering kali syarat-syarat yang seharusnya di penuhi tersebut tidak sepenuhnya ditaati oleh suami. Sementara itu, juga tidak ada control dari pengadilan untuk menjamin bahwa syarat itu dijalankan. Bahkan dalam beberapa kasus, meski belum atau tidak ada persetujuan dari istri sebelumnya, poligami tetap bisa dilakukan.

\section{Peraturan Poligami bagi Pegawai Negri Sipil}

Di Indonesia pengaturan poligami bagi pegawai negri diberi kekhususan, selain ketentuan yang secara umum berlaku bagi masyarakat. Oleh karena itu, selain harus memenuhi ketentuan umum yang berlaku terhadapnya, berlaku pula peraturan Pemerintah No. 10 tahun 1983 Tentang Perkawinan dan Perceraian Bagi Pegawai Negeri Sipil sebagaimana telah diubah dengan Peraturan Pemerintah Nomor 45 tahun 1990 Tentang Perubahan Atas 
DE LEGA LATA

Jurnal Ilmu Hukum

FAKULTAS HUKUM UMSU
Poligami Bagi Aparatur...(Rahmayani Saragih) Volume 3 Nomor 2, Juli-Desember 2018, 230-243 DOI: https://doi.org/10.30596/dll.v3i2.3160

Peratutan Pemerintah Nomor 10 tahun 1983 Tentang Izin Perkawinan dan Perceraian bagi Pegawai Negeri Sipil jo Surat Edaran Badan Administrasi Badan Kepegawaian Negara Peraturan Pemerintah jo. 45 tahun 1990 dan surat Edaran Badan Administrasi Badan Kepegawaian Negara Nomor 08/SE/1983 dan Nomor 48/SE/1990 tentang Petunjuk Pelaksanaan Peraturan Pemerintah Nomor 45 Tahun 1990 Tentang Perubahan Atas Peratutan Pemerintah Nomor 10 tahun 1983 Tentang Izin Perkawinan dan Perceraian bagi Pegawai Negeri Sipil.

Kekhususan tersebut dilandasi pemikiran bahwa pegawai negri sipil merupakan abdi negara yang diharapkan dapat menjadi teladan dalam masyarakat. Seorang pegawai negri diharapkan bertindak hati-hati sebelum memutuskan untuk berpoligami. Dalam pengajuan izin berpoligami diperlukan lebih ahuli izin tertulis dari pejabat atasannya disertai dasar alasan. Untuk itu, harus dipenuhi adanya syarat alternatif sebagai dasar alasan berpoligami yang harus dibuktikan dengan surat keterangan dokter pemerintah.

Syarat alternatif merupakan dasar alasan diperbolehkan seorang pegawai negri sipil laki-laki untuk menikah lagi, yaitu sama seperti ketentuan umum dalam UU Perkawinan meliputi alasan bahwa:

a. Istri pegawai negeri sipil tersebut tidak dapat menjalankan kewajiban sebagai istri akibat menderita penyakit jasmani ataupun rohani.

b. Istri pegawai negeri sipil tersebut memiliki cacat badan atau penyakit yang tidak dapat disembuhkan

c. Istri pegawai negeri sipil tersebut tidak dapat melahirkan keturunan setelah menikah sekurang-kurangnya 10 tahun.

Sedangkan syarat kumulatif merupakan syarat-syarat yang harus dipenuhi oleh seorang pegawai negeri sipil laki-laki yang berkeinginan menikah lagi, sama seperti syarat-syarat umum berpoligami, tetapi harus disahkan oleh atasan pegawai negri sipil tersebut dengan kriteria serendah-rendahnya pejabat esolan IV:

a. Adanya persetujuan tertulis dari seorang istri atau istri-istri lain dari pegawai negeri sipil kalau memiliki beberapa istri

b. Adanya kepastian bahwa pegawai negeri sipil yang akan menikah lagi mempunyai penghasilan yang cukup untuk menjamin keperluan hudup istri-istri dan anak-anak mereka. Kepastian jaminan penghasilan tersebut harus dibuktikan dengan surat keterangan pajak penghasilan

c. Adanya jaminan tertulis bahwa pegawai negeri sipil yang hendak menikah tersebut akan berlaku adil terhadap istri-istri dan anak-anak mereka.

Sebelum pejabat atasan pegawai negeri sipil tersebut mengambil keputusan, terlebih dahulu dia harus memberikan nasihat kepada pegawai negeri sipil laki-laki yang hendak menikah lagi juga kepada istrinya. Hal itu dimaksudkan agar setiap pihak berpikir lagi dan jika bisa dicarikan penyelessaian lain sehingga poligami sejauh mungkin dapat dihindari.

Jika semua upaya telah dilakukan dan pejabat atasan beranggapan bahwa tindakan 
DE LEGA LATA

Jurnal Ilmu Hukum

FAKULTAS HUKUM UMSU
Poligami Bagi Aparatur...(Rahmayani Saragih)

Volume 3 Nomor 2, Juli-Desember 2018, 230-243 DOI: https://doi.org/10.30596/dll.v3i2.3160

poligami tidak akan mengganggu kelancaran pelaksanaan tugas kedinasan, permintaan izin berpoligami tersebut dapat diberikan. Dari apa yang telah dipaparkan tampak bahwa di Indonesia, masalah poligmi mempunyai suatu landasan hukum, yaitu Undang-Undang Nomor 1 tahun 1974 tentang Perkawinan yang pada hakekatnya menganut asas monogami, tetapi memungkinkan dilakukan poligami. Pengaturan Pemerintah No. 9 tahun 1975 tentang pelaksanaan UU No. 1 tahun 1974 mengatur prosedur poligami bagi masyarakat secara umum. Sedangkan peraturan Pemerintah No. 10 tahun 1983 peraturan Pemerintah No. 45 tahun 1990 serta Surat Edaran No. 08/SE/83 khusus mengatur izin poligami bagi pegawai negeri sipil. Selain itu, Inpres Nomor 1 tahun 1991 tentang Kompilasi Hukum Islam berlaku khusus bagi masyarakat Muslim.

Masalah poligami merupakan masalah yang cukup controversial, menimbulkan pro dan kontra di masyarakat. Pihak yang pro mendasarkan pada kaidah ketentuan agama. Sedangkan pihak yang kontra memandang poligami sebagai tindakan sewenang-wenang dan merupakan bentuk pengunggulan kaum laki-laki. Alasan yang dapat dipakai untuk melakukan poligami juga ditentukan secara definitif dan sangat bisa gender, yaitu istri tidak dapat menjalankan fungsi sebagai istri, tidak dapat melahirkan keturunan, sakit dan cacat fisik atau mental.

Menurut pandangan penulis, dianutnya asas monogami dalam ketentuan Pasal 3 ayat 1 Undang-Undang Nomor 1 Tahun 1974 tentang Perkawinan mencerminkan pengutamaan diterapkannya asas monogami dalam setiap perkawinan. Hal tersebut juga dimaksudkan untuk menghargai pandangan sebagai masyarakat muslim yang membolehkan poligami syarat harus mampu berlaku adil. Agama islam secara legal mengakui institusi poligami meskipun dengan pembatasan yang cukup ketat. Poligami menjadi bagian konsep yang wajar dan tetap ideal pada setiap jaman. Namun, penerapan harus memperhatikan ketentuan hadis yang menyatakan bahwa Nabi melarang poligami jika melukai hati perempuan. Tindakan tersebut dibolehkan dengan syarat ketat, harus mampu menjaga perasaan istri-istrinya.

Dengan demikian, secara filosofis dicantumkan ketentuan yang membolehkan adanya poligami dalam Pasal 3 ayat 2 Undang-Undang Nomor 1 Tahun 1974 tentang Perkawinan bukan dimaksudkan sebagai bentuk pelecehan, diskriminasi dan pengunggulan kaum lakilaki. Praktik dalam masyarakat tentang poligami yang sering menampakkan kesewenangwenangan suami terhaddap istri tidak dapat digunakan untuk generalisasi bahwa poligami pasti diskriminatif wujud penindasan kaum suami terhadap istri.

Oleh karena itu yang perlu dilakukan adalah mengidentifikasi akar permasalahan yang sebenarnya terjadi kemudian mencari alternatif pemecahan terhadap masalah tersebut. Dengan demikian, dari aspek ketentuan hukumnya, ketentuan Undang-Undang Nomor 1 Tahun 1974 tentang Perkawinan tersebut sudah cukup baik dalam arti secara tegas ditentukan bahwa pada asasnya dianut monogami. Selain itu, penerapan poligami dimungkinkan jika para pihak menyetujui dan tidak lain ditujukan untuk mengatasi suatu masalah yang tidak dapat diselesaikan. Di dalam pelaksanaan memang menjumpai banyak sekali pelanggaran yang terjadi. Seperti tidak dipenuhinya dasar alasan atau tidak dipenuhinya semua persyaratan untuk menikah lagi, tetapi permohonan izin poligami bisa dikabulkan. 
DE LEGA LATA

Jurnal Ilmu Hukum

FAKULTAS HUKUM UMSU
Poligami Bagi Aparatur...(Rahmayani Saragih) Volume 3 Nomor 2, Juli-Desember 2018, 230-243 DOI: https://doi.org/10.30596/dll.v3i2.3160

Aturan hukum yang ideal harus diterapkan sering kali disampimgkan. Banyak poligami dilakukan dengan tidak memenuhi dasar alasan dan keseluruhan syarat yang harus dipenuhi, disisi lain, akibat ketatnya prosedur yang harus dilalui untuk berpoligami mengakibatkan masyarakat lebih senang memilih menikah siri bahkan hidup bersama tanpa ikatan pernikahan.

Tudingan yang menyudutkan Indonesia bahwa sebagai bangsa beradap seharusnya tidak dibolehkan adanya poligami tidak dapat dibenarkan karena pada dasarnya kemungkinan poligami dibolehkan adalah ditujukan untuk kemaslahatan para pihak yang bersangkutan, bahkan untuk mengunungkan kedudukan kaum laki-laki dan pelecehan bagi kaum perempuan.

Disisi lain, kita melihat bahwa praktik Negara-negara yang menerapkan monogami tidak jauh lebih baik dari pada Negara kita. Poligami dilarang, tetapi hidup bersama tanpa ikatan perkawinan yang sebenarnya mengingkari hakekat nilai kemanusiaan marak dilakukan. Seakan tidak ada perbedaan anatara manusia sebagai makhluk mulia dan binatang yang bebas berganti-ganti pasangan. Hal yang lebih berbahaya adalah kemungkinan penularan penyakit kotor HIV/AIDS akibat pola ganti-ganti pasangan.

\section{KESIMPULAN DAN SARAN}

Kesimpulan

Di Indonesia, masalah poligami diatur dalam berbagai ketentuan hukum, seperti dalam Undang-Undang Nomor 1 Tahun 1974 tentang Perkawinan, Peraturan Pemerintah Nomor 9 tahun 1975 tentang pelaksanaan Undang-Undang Nomor 1 Tahun 1974 tentang Perkawinan yang mengatur prosedur poligami bagi masyarakat secara umum. Sedangkan peraturan pemerintah Nomor 45 tahun 1990 serta Surat Edaran Nomor 08/SE/83 khusus mengatur izin poligami bagi pegawai negeri sipil. Selain itu, Inpres Nomor 1 tahun 1991 tentang Kompilasi Hukum Islam berlaku khusus bagi masyarakat Muslim. Undang-undang Nomor 1 tahun 1974 tentang Perkawinan pada hakekatnya menganut asas monogami, tetapi memungkinkan dilakukannya poligami dalam kondisi khusus dengan memenuhi dasar alasan dan keseluruhan persyaratan yang ditentukan.

Keseluruhan persyaratan untuk berpoligami menurut UU Perkawinan cukup berat. Apalagi bagi pegawai negeri sipil, yaitu adanya persetujuan dari seorang istri atau istri-istri jika telah memiliki beberapa istri, adanya kepastian bahwa suami mampu menjamin keperluan hidup istri-istri dan anak-anak mereka. Dalam prakteknya, adanya kecendrungan akibat sulitnya prosedur yang harus dilalui untuk berpoligami mengakibatkan pada dilakukannya nikah siri ataupun hidup bersama tanpa ikatan perkawinan.

\section{Saran}

Bahwasannya Perlu dikaji lebih lanjut mengenai berbagai faktor yang berpengaruh terhadap kurang efektifnya keyentuan hukum yang mengatur poligami. Harus diupayakan penegakan hukum secara konsisten dan sosialisasi hukum ketentuan UU Perkawinan secara berkelanjutan. Pengadilan atau pejabat atasan yang berwenang memberi izin berpoligami 
Jurnal Ilmu Hukum FAKULTAS HUKUM UMSU
Poligami Bagi Aparatur...(Rahmayani Saragih) Volume 3 Nomor 2, Juli-Desember 2018, 230-243 DOI: https://doi.org/10.30596/dll.v3i2.3160

harus selektif dan berhati-hati sebelum mengabulkan permohonan itu. Dalam hal diberikan izin berpoligami harus diupayakan adanya suatu control dari pengadilan atau pejabat atasan untuk menjamin bahwa syarat-syarat itu dijalankan. Bahwa perlu adanya suri teladan dari para pemimpin, pemuka, pramuka atau anutan masyarakat untuk memberikan contoh yang baik, poligami jangan dijadikan sesuatu yang dianggap mudah. 


\section{DAFTAR PUSTAKA}

Asosiasi Perempuan Indonesia untuk Keadilan. Kelompok Perempuan untuk pemantauan Pelaksanaan Konvensi. Pelaksanaan Konvensi Penghapusan segala bentuk Diskriminasi terhadap Perempuan. Laporan Independen kepada komite PBB untuk penghapusan Diskriminasi terhadap perempuan, Penyunting: Nusyahbani Katjasungkana, Liza Hadiz.

Astute, Made Sadhi. (1998). Selayang Pandang Peran Wanita Dalam Pembangunan Dan Perlimdungan Dalam Hukum. Arena Hukum No. 5 tahun 2 FH Unibraw, Malang

Instruksi Presiden Nomor 1 Tahun 1991 tentang Kompilasi Hukum Islam.

Peraturan Pemerintah Nomor 9 Tahun 1975 tentang pelaksanaan Undang-Undang Nomor 1 Tahun 1974.

Peraturan Pemerintah Nomor 10 Tahun 1983 Peraturan Pemerintah No. 45 Tahun 1990.

Rahmawati, Rasyidah. (2005). Wacana Poligami di Indonesia. Bandung: Mizan.

Surat Edaran Nomor 09/SE/83 Khusus Mengatur Izin Poligami Bagi Pegawai Negeri Sipil.

Undang-Undang Nomor. 1 Tahun 1974 tentang Perkawinan.

Yayasan Penyelenggara Penerjemah/Penafsiran Al-Quran. (1990) Al-Qur'an dan terjemahannya. Jakarta: Pustaka Panjimas. 